\title{
Karakteristik Sifat Fisik dan Kimia Edible Film Pati Sagu Rumbia (Metroxylon sagu Rottb) untuk Bahan Baku Cangkang Kapsul Characteristics of Physical and Chemical Properties of Edible Film of Rumbia Sago Starch (Metroxylon sagu Rottb) for Capsule Shell Materials
}

\author{
Hamlan Ihsan ${ }^{\text {a* }}$, Nadra Khairiah ${ }^{\mathrm{a}}$, Rufida ${ }^{\mathrm{a}}$ \\ ${ }^{a}$ Balai Riset dan Standardisasi Industri Banjarbaru \\ JI. Panglima Batur Barat No. 2, Banjarbaru, Kalimantan Selatan, 70711 Indonesia \\ *Email : hamlan.ihsan@ymail.com
}

Diterima 10 Juni 2018 Disetujui 08 November 2018 Diterbitkan 29 Desember 2018

\begin{abstract}
ABSTRAK
Tujuan penelitian ini adalah untuk mempelajari sifat fisik dan kimia pati sagu rumbia (Metroxylon sagu Rottb) untuk bahan baku cangkang kapsul. Penelitian diawali dengan pembuatan pati, dilanjutkan dengan pembuatan edible film dengan modifikasi karagenan ( $20 \%$ dan $30 \%$ b/b) terhadap bahan utama. Hasil uji organoleptik berupa warna dan bau adalah normal. Pengujian kadar air diperoleh hasil untuk sagu basah $12,55 \%$ dan sagu kering 5,38\%. Penambahan karagenan meningkatkan kadar air tetapi tidak melebihi baku mutu SNI gelatin yaitu maksimal $16 \%$. Kadar abu dari sagu segar $0,36 \%$ dan $1,09 \%$ untuk sagu kering dan mengalami peningkatan yang signifikan terhadap penambahan karagenan. Hasil pH dari semua variasi perlakuan sesuai dengan SNI yaitu 5,5-7,0 serta kandungan logam berat yang negatif pada pengukuran menggunakan AAS. Berdasarkan hasil pengujian viskositas dengan metode Brookfield, semakin tinggi kadar karagenan, viskositas semakin rendah, sedangkan hasil uji kuat tarik berdasarkan metode ASTM D $882-2002$ memberikan hasil positif untuk sagu kering $21,05 \mathrm{~kg} / \mathrm{cm}^{2}$; sedangkan sagu segar dengan konsentrasi karagenan $20 \%$ dan 30\% mempunyai kuat tarik sebesar 5,33 $\mathrm{kg} / \mathrm{cm}^{2}$; dan $18,18 \mathrm{~kg} / \mathrm{cm}^{2}$. Hasil penelitian menunjukkan, pati sagu memiliki potensi untuk dijadikan bahan baku pembuatan soft capsule dengan melakukan modifikasi untuk memperbaiki dan meningkatkan sifat fisik guna memenuhi syarat mutu.
\end{abstract}

Kata Kunci : gelatinisasi, kapsul, karagenan, sagu, substitusi

\section{ABSTRACT}

The purpose of this research was to analyze the physical and chemical properties of sago starch edible film (Metroxylon sagu Rottb) as capsule shells material. The research was started with the extraction of the rumbia starch, and was followed with the production of edible film added with modified carrageenan concentrations $(20 \%$ and $30 \% \mathrm{w} / \mathrm{w})$ to the main compound. Organoleptic test showed that the color and odor of the films were normal. Water content of wet sago and dry sago was $12.55 \%$, and $5.38 \%$, respectively. Although the addition of carrageenan increased the water content but still corresponded with SNI gelatin quality standard with a maximum of water content of $16 \%$. The ash content of fresh sago and dry sago was $0.36 \%$ and $1.09 \%$, respectively, and the content increased significantly with the addition of carrageenan. The $\mathrm{pH}$ of all varied samples was $5.5-7.0$, and the $\mathrm{pH}$ was in accordance with SNI. Meanwhile, the heavy metal content of the samples measured by means of AAS was negative. Based on viscosity testing withBrookfield method, high carrageenan concentration led to low viscosit. tensile strength test based on ASTM D 882-2002 gave positive results for dry sago (21.05 $\mathrm{kg} / \mathrm{cm}^{2}$ ) whereas fresh sago with modified $20 \%$ and $30 \%$ carrageenan had tensile strength of $5.33 \mathrm{~kg} / \mathrm{cm}^{2}$ and $18.18 \mathrm{~kg} / \mathrm{cm}^{2}$, respectively. The results showed that sago starch had the potential as a raw material for producing soft capsules by modified composition to 
enhance physical and mechanical properties in order to meet the quality standard of edible film.

Keywords : gelatinisation, capsule, carrageenan, sago, substitution

\section{PENDAHULUAN}

Sagu merupakan komoditas yang potensial untuk digunakan sebagai substitusi pangan dan sumber karbohidrat dilihat dari bahan baku yang berlimpah dan potensi yang belum dimanfaatkan secara maksimal (Polyana \& Puturuhu, 2016). Menurut Fatriani (2010) pohon sagu/rumbia merupakan salah satu jenis tumbuhan yang memiliki kandungan pati yang tinggi. Batang sagu mempunyai panjang sekitar $10-15 \mathrm{~m}$ dengan garis tengah $15-30$ $\mathrm{cm}$. Tanaman ini tumbuh baik pada ketinggian tanah antara $0-700 \mathrm{mdpl}$, dengan curah hujan antara $2.000-4.000$ $\mathrm{mm} /$ th dan merata sepanjang tahun. Suhu optimal untuk pertumbuhan sagu berkisar antara $24,5-29^{\circ} \mathrm{C}$ dan suhu minimal $15^{\circ} \mathrm{C}$, dengan kelembaban nisbi $90 \%$. Pohon sagu dapat ditanam di daerah yang mempunyai kelembaban nisbi udara $40 \%$. Kelembaban yang optimal untuk pertumbuhannya adalah $60 \%$.

Gelatin merupakan salah satu biopolimer yang penggunaannya sangat luas dalam bidang pangan dan farmasi. Berdasarkan data, produksi gelatin mencapai 326.000 ton/tahun, urutan pertama adalah yang berasal dari kulit babi (46\%), kulit sapi $(29,4 \%)$, kemudian dari tulang sapi dan diikuti bahan lain masingmasing sebesar $(23,1 \%)$ dan $(1,5 \%)$ (Suptijah, Suseno, \& Anwar, 2013). Penggunaan gelatin hewani sebagai bahan baku kapsul memiliki resiko seperti rentan kontaminasi virus dan isu halal. Pemanfaatan pati sagu termodifikasi sebagai bahan cangkang kapsul akan meningkatkan pemanfaatannya yang selama ini masih terbatas sebagai sumber pangan. Eksploitasi pohon sagu masih terbatas pada pemanfaatan daun sebagai bahan atap (Fatriani, 2010), pelepah sebagai lem, dan tepung sagu sebagai pengganti karbohidrat. Pada penelitian Suptijah et al., (2013) dilakukan penambahan k-karagenan yang merupakan polisakarida sulfat yang diekstrak dari beberapa spesies rumput laut merah (Rhodophyceae) yang berfungsi untuk memodifikasi tekstur bahan utama, sehingga menghasilkan produk yang memiliki elastisitas yang bagus. Karagenan dibagi berdasarkan kandungan sulfatnya terdiri dari kappa $(\mathrm{k})$, ioda $(\mathrm{l})$, dan lamda $(\Lambda)$ untuk kandungan sulfatnya adalah $20 \%$, $33 \%$, dan 42\% (Herliany, Santoso, \& Salamah, 2013).

Alternatif penggunaan sagu sebagai bahan baku pengganti gelatin merupakan hal yang positif. Berdasarkan kemampuannya pati sagu dapat mengalami proses gelatinasi, sehingga dengan kemampuannya tersebut pada penelitian ini juga akan dilihat sifat-sifat yang terjadi dari pencampuran dengan karagenan yang memiliki sifat sebagai bahan pengental serta pembentuk gel. Penelitian ini bertujuan untuk mempelajari sifat fisik dan kimia edible film dari pati sagu dengan penambahan karagenan sesuai dengan baku mutu SNI dan Farmakope Indonesia edisi IV untuk dapat diaplikasikan sebagai bahan baku pembuatan cangkang kapsul.

\section{BAHAN DAN METODE}

\subsection{Bahan dan Peralatan}

Bahan yang digunakan dalam penelitian ini meliputi, $1 \mathrm{~kg}$ tepung sagu (merk kuda laut), $20 \mathrm{~kg}$ batang rumbia (Metroxylon sagu Rottb) yang di ambil dari Desa Margasari Kab. Tapin, dan 100 g kkaragenan (komersial), $100 \mathrm{~g}$ gelatin (komersial), aquades, plastik tahan panas dan kertas saring Whatman No.41. Peralatan yang digunakan antara lain adalah hot plate stirrer, magnetic stirrer, beaker glass, $\mathrm{pH}$ meter, oven, tanur, $A A S$ GBC Avanta, gelas ukur, dan peralatan gelas laboratorium lainnya.

\subsection{Metode Penelitian \\ 2.2.1 Proses Pembuatan Pati Sagu}


Penelitian ini diawali dengan pengupasan batang pohon rumbia dari kulit batangnya, kemudian dilakukan pencucian dengan air mengalir untuk membersihkan sisa kotoran. Potongan rumbia dihancurkan dengan cara diparut sehingga membentuk bubur, kemudian disaring dengan menggunakan kain saringan sehingga menghasilkan ampas dan filtrat. Ampas disaring lagi dengan perbandingan 1:2 (ampas dan air) sehingga didapatkan filtrat. Hasil filtrat kemudian diendapkan selama 3-5 jam dengan 4 kali pencucian. Endapan yang dihasilkan dipisahkan dari air dan dikeringkan pada suhu $60^{\circ} \mathrm{C}$ selama 5 jam. Pati kering lalu dihaluskan sehingga dapat digunakan sebagai sampel penelitian (Saputro, Dovan, Kurniawan, \& Nata, 2016)

\subsubsection{Pembuatan Edible Film Pati Sagu dan Karagenan}

Tahapan selanjutnya yaitu dilakukan karakterisasi dan pembuatan lembaran edible film menggunakan sampel uji pati sagu segar, tepung sagu (komersial), gelatin (komersial), dan dengan modifikasi karagenan $(20 \%$ dan $30 \% \mathrm{~b} / \mathrm{b})$ terhadap pati sagu segar, dan tepung sagu. Proses pembuatan lembaran edible film mengikuti metode Wattimena, Ega, \& Polnaya (2016) dengan beberapa modifikasi pada tahapannya, sampel uji sebanyak $10 \mathrm{~g}$ dilarutkan dalam aquadest $100 \mathrm{~mL}$, dilakukan pada suhu $90^{\circ} \mathrm{C}$ untuk proses gelatinasinya. Selanjutnya larutan diaduk selama 1 menit sampai proses gelatinasi terbentuk. Setelah selesai larutan dipindahkan pada plat cetakan untuk pembentukan edible film dari sampel uji, pengeringan dilakukan pada suhu $40^{\circ} \mathrm{C}$ selama 14 jam untuk menghilangkan kadar airnya. Sebelum dilakukan analisis edible film disimpan dalam wadah dengan kelembaban relatif $50 \%$ dan pada suhu kamar (Ozdemir \& Floros, 2008).

\subsubsection{Karakterisasi dan Pengujian Sifat Fisik dan Kimia Edible Film Pati Sagu dan Karagenan}

Sampel uji penelitian untuk uji kadar air dan kadar abu menggunakan metode gravimetri, dengan melakukan penimbangan sampel uji sebanyak $2 \mathrm{~g}$ kemudian dimasukkan dalam cawan porselin yang diketahui berat awalnya. Kemudian dipanaskan dalam oven pada suhu $105^{\circ} \mathrm{C}$ selama 1,5 jam dilanjutkan dengan pendinginan dalam desikator selama 15 menit, dilakukan pencatatan berat konstan dari sampel (berat akhir diketahui, yaitu sebelum dipanaskan). Pengujian kadar abu dilakukan dengan diabukan menggunakan tanur selama 20 menit pada suhu $545^{\circ} \mathrm{C}$ dan didinginkan dalam desikator selama 1 jam dan dilakukan penimbangan hingga berat konstan.

Pengujian nilai rendemen menggunakan kalkulasi dari data yang didapat berdasarkan berat timbangan. Pengukuran viskositas menggunakan Brookfield viscometer. Sampel uji dibuat dengan perbandingan (b/v) 1:10 sebanyak $250 \mathrm{~mL}$. Pengujian $\mathrm{pH}$ dari sampel uji dilakukan menggunakan $\mathrm{pH}$ meter, sedangkan pengujian warna dan bau dilakukan secara organoleptik. Kandungan logam berat dianalisis menggunakan Atomic Absorption Spectroscopy (AAS) merk GBC Avanta.

Pengujian sifat fisik dan kandungan kimia dari edible film pati sagu dan dengan modifikasinya, mengacu pada SNI 063735-1995 tentang syarat dari gelatin. Pengujian kuat tarik berdasarkan ASTM D 882-2002 diukur dengan menggunakan alat tensile strength, sesuai dengan yang dilakukan Wattimena et al., (2016). Sampel film dipotong persegi panjang dengan ukuran $5 \times 5 \mathrm{~cm}$, kemudian ketebalan ditentukan berdasarkan rerata dari pengukuran tiga posisi yang berbeda.

\section{HASIL DAN PEMBAHASAN}

\subsection{Hasil Proses Pembuatan Pati Sagu dan Edible film}

Proses pembuatan edible film yang diawali dengan proses penyaringan dari batang rumbia yang telah dihaluskan, kemudian dilakukan pengeringan sehingga diperoleh lembaran film. Hasil uji nilai rendemen dari pati sagu pohon rumbia yang dibuat sebagai edible film disajikan pada Gambar 1. 


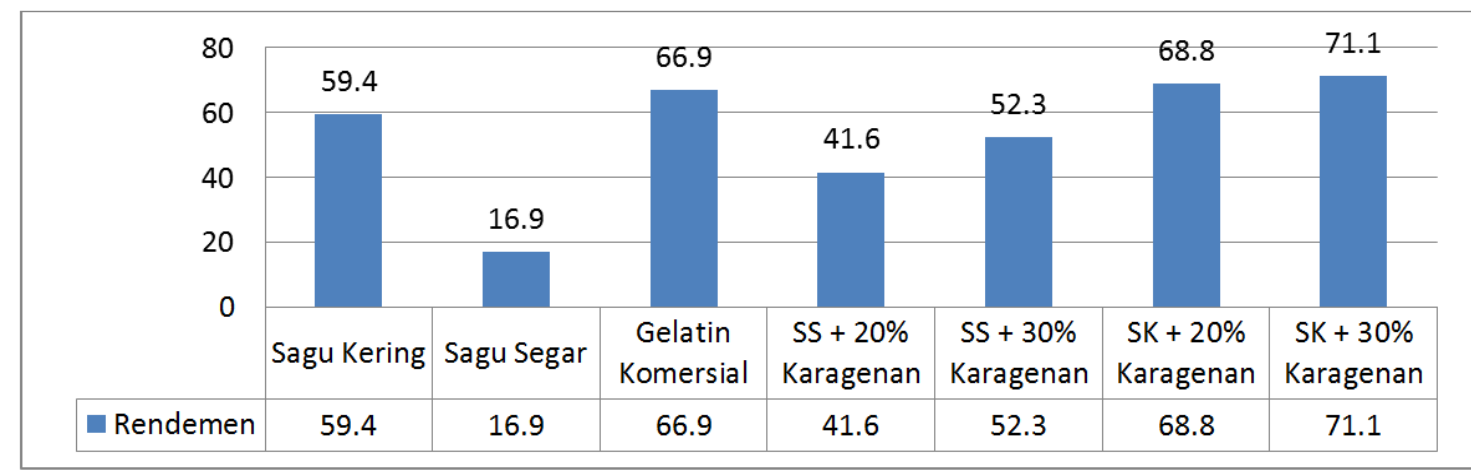

Gambar 1. Grafik Nilai Rendemen (\%) Edible Film (ss: sagu segar; sk: sagu kering)

Nilai rendemen tertinggi ada pada formulasi sagu kering dengan $30 \%$ karagenan, sedangkan untuk rendemen terendah ada pada formulasi sagu segar (Gambar 1). Rendemen pati sagu dipengaruhi secara nyata oleh jenis bahan baku yang digunakan. Pada data terlihat kisaran rendemen yang didapat yaitu antara $16,9 \%$ sampai dengan yang paling tinggi adalah $71,1 \%$, pada penelitian Hakim, Wibowo, Arfini, \& Peranginangin (2011) rendemen yang diperoleh antara $21,76 \%$ - 31,77\%. Hal ini menunjukkan bahwa penambahan agen modifikasi menggunakan karagenan mampu meningkatkan nilai rendemen.

Rendemen dari sagu segar dapat bervariasi tergantung beberapa faktor seperti teknik penyaringan dan perbandingan air yang digunakan untuk memperoleh pati sagu (Purnama, 2003). Selain itu juga rendemen juga dapat dipengaruhi oleh waktu dan suhu filtrasi serta konsentrasi dari bahan baku (Basmal, Syarifudin, \& Ma'ruf, 2003).

\subsection{Hasil Pembuatan Edible Film Pati Sagu dan Karagenan \\ Edible film yang dihasilkan pada} penelitian ini memberikan hasil yang cukup berbeda, baik dari segi warna ataupun waktu yang diperlukan pada proses gelatinasi. Penambahan karagenan memberikan perbedaan hasil yang cukup signifikan di beberapa parameter pengujian. Berikut data hasil penelitian disajikan pada Tabel 1.

Pengujian organoleptik warna dan bau dilakukan berdasarkan panel perseorangan yang memiliki kepekaan spesifik terhadap sampel uji di bidang pangan. Hasil uji pada edible film dari variasi penelitian secara keseluruhan menunjukkan nilai normal (dapat diterima). Sedangkan untuk nilai kadar air dan kadar abu yang dalam analisanya menggunakan metode gravimetri, penambahan karagenan sebagai agen modifikasi memberikan kenaikan terhadap nilai kadar air dan kadar abu.

Tabel 1. Data Hasil Karakterisasi Edible Film Berdasarkan SNI 06-3735-1995 (Gelatin) dan Farmakope Indonesia Ed.IV

\begin{tabular}{|c|c|c|c|c|c|c|c|c|c|c|}
\hline No. & Parameter & $\begin{array}{c}\text { Gelatin } \\
\text { komersial }\end{array}$ & Sagu segar & Sagu kering & $\begin{array}{c}\text { Sagu segar } \\
+20 \% \\
\text { karagenan }\end{array}$ & $\begin{array}{l}\text { Sagu segar } \\
+30 \% \\
\text { karagenan }\end{array}$ & $\begin{array}{l}\text { Sagu kering } \\
+20 \% \\
\text { karagenan }\end{array}$ & $\begin{array}{l}\text { Sagu kering } \\
+30 \% \\
\text { karagenan }\end{array}$ & SNI Gelatin & FI. Ed IV \\
\hline 1 & Warna & $\begin{array}{c}\text { Tidak } \\
\text { berwarna }\end{array}$ & $\begin{array}{c}\text { Tidak } \\
\text { berwarna }\end{array}$ & $\begin{array}{l}\text { Keabu- } \\
\text { abuan }\end{array}$ & $\begin{array}{c}\text { Tidak } \\
\text { berwarna }\end{array}$ & $\begin{array}{c}\text { Tidak } \\
\text { berwarna }\end{array}$ & $\begin{array}{l}\text { Keabu- } \\
\text { abuan }\end{array}$ & $\begin{array}{l}\text { Keabu- } \\
\text { abuan }\end{array}$ & $\begin{array}{c}\text { Tidak } \\
\text { berwarna }\end{array}$ & - \\
\hline 2 & Bau & Normal & Normal & Normal & Normal & Normal & Normal & Normal & Normal & - \\
\hline 3 & Kadar air (\%) & 14,06 & 12,55 & 5,38 & 13,67 & 13,25 & 13,31 & 13,67 & Maks. 16 & 14 \\
\hline 4 & Kadar abu (\%) & 1,18 & 0,36 & 1,09 & 5,68 & 6,97 & 5,38 & 7,61 & Maks. 3,25 & $1-2$ \\
\hline 5 & Suhu $\left({ }^{\circ} \mathrm{C}\right)$ & 29,0 & 27,8 & 27,8 & 27,7 & 28,0 & 27,7 & 28,2 & - & - \\
\hline 6 & $\mathrm{pH}$ & 4,974 & 5,927 & 4,559 & 7,045 & 7,345 & 6,196 & 7,097 & - & $5,5-7,0$ \\
\hline
\end{tabular}


Penelitian yang dilakukan oleh Suptijah, Suseno, \& Kurniawati (2012) menggunakan ikan cucut (C. punctatum) memberikan hasil untuk kadar air dan kadar abu adalah 9,33\% dan 2,55\%. Sedangkan untuk penelitian yang dilakukan kadar air dan kadar abu dapat dilihat pada Tabel 1. Kadar air terendah 5,38\% untuk sagu kering dan kadar air tertinggi adalah $14,06 \%$ untuk gelatin komersial. Kadar abu terendah $0,36 \%$ untuk sagu segar dan kadar abu tertinggi $7,61 \%$ untuk sagu kering dengan $30 \%$ karagenan. Hasil uji kadar air masih dalam rentang standar yang dipersyaratkan baik berdasarkan SNI 06-3735-1995 dan FI. Ed IV, sedangkan untuk kadar abu dengan penambahan karagenan menyebabkan kenaikan yang signifikan.

Besar kecilnya nilai kadar abu dipengaruhi oleh proses demineralisasi dan pencucian, semakin banyak mineral yang tereliminasi akibat pencucian maka nilai dari kadar abu akan semakin rendah. Paranginangin, Mulyasari, Sari, \& Tazwir (2005) menyatakan bahwa masih adanya komponen mineral yang terikat pada kolagen kulit ikan sehingga terbawa pada saat analisis kadar abu. Menurut Sukri \& Nanda (2006), karagenan atau ekstrak rumput laut dari jenis kappa merupakan sumber mineral alami yang kaya akan kandungan mineral (Sukri \& Nanda, 2006).

Suptijah et al. (2012) menyatakan nilai derajat keasaman $(\mathrm{pH})$ merupakan salah satu parameter penting dalam standar mutu gelatin. Nilai $\mathrm{pH}$ yang dianalisis mempengaruhi sifat-sifat lainnya, misalnya viskositas, dan kekuatan gel, serta dapat berpengaruh pada aplikasinya.
Berdasarkan Tabel 1, hasil uji derajat keasaman pada suhu $20^{\circ} \mathrm{C}$ sesuai dengan standar FI. Ed IV yaitu 5,5-7,0. Data hasil uji $\mathrm{pH}$ adalah 5,927 untuk sagu segar; sagu segar dengan 20\% karagenan adalah 7,045 ; sagu kering dengan $20 \%$ karagenan adalah 6,196, sedangkan untuk variasi penelitian yang lain masih di luar dari standar mutu. Berdasarkan penelitian yang dilakukan Bunga et al. (2013) menyatakan bahwa karagenan merupakan sumber mineral alam yang tinggi, sehingga dari kandungan mineral alam yang tinggi tersebut akan mempengaruhi derajat keasaman.

\subsection{Sifat Fisik Kimia Edible Film Sagu dan Karagenan}

Hasil dari pengujian ini adalah untuk melihat sifat-sifat edible film yang dibuat dari tujuh variasi percobaan. Berikut data hasil penelitian disajikan pada Tabel 2 .

Kandungan logam menunjukkan hasil yang negatif (Tabel 2), artinya sampel memiliki nilai dibawah dari regulasi SNI gelatin. Beberapa penelitian yang dilakukan untuk pengamatan logam berat pada tanaman yang tumbuh di perairan atau rawa disebutkan bahwa penyerapan logam berat oleh akar pohon dipengaruhi sistem perakaran dan luasan permukaan akarnya, pohon rumbia yang merupakan tanaman dari family Palmae yang tumbuh dengan cara bertunas berbeda dengan tanaman mangrove yang memiliki sistem perakaran langsung menghujam ke dalam tanah, sehingga memiliki kemampuan menyerap logam berat yang tinggi (Heriyanto, 2011).

Tabel 2. Data Hasil Untuk Sifat Fisik dan Kimia Edible Film

\begin{tabular}{|c|c|c|c|c|c|c|c|c|c|c|}
\hline No & Parameter & $\begin{array}{c}\text { Gelatin } \\
\text { komersial }\end{array}$ & Sagu segar & Sagu kering & $\begin{array}{l}\text { Sagu segar } \\
\quad+20 \% \\
\text { karagenan }\end{array}$ & $\begin{array}{l}\text { Sagu segar } \\
+30 \% \\
\text { karagenan }\end{array}$ & $\begin{array}{l}\text { Sagu kering } \\
\quad+20 \% \\
\text { karagenan }\end{array}$ & $\begin{array}{c}\text { Sagu kering + } \\
30 \% \\
\text { karagenan }\end{array}$ & $\begin{array}{c}\text { SNI } \\
\text { Gelatin }\end{array}$ & FI. Ed IV \\
\hline 1 & Viskositas (cP) & 7,5 & 76,5 & 86,5 & 86,5 & 28,5 & 35 & 28 & - & $3,2-4,7$ (cPs) \\
\hline 2 & Kuat tarik $\left(\mathrm{Kg} / \mathrm{cm}^{2}\right)$ & - & - & 21,05 & 5,33 & 18,18 & - & - & & - \\
\hline 3 & Arsen (ppb) & $<0,0003$ & $<0,0003$ & $<0,0003$ & $<0,0003$ & $<0,0003$ & $<0,0003$ & $<0,0003$ & $2 \mathrm{ppm}$ & - \\
\hline 4 & Cadmium (ppm) & $<0,001$ & $<0,001$ & $<0,001$ & $<0,001$ & $<0,001$ & $<0,001$ & $<0,001$ & - & - \\
\hline 5 & $\mathrm{~Pb}(\mu \mathrm{g} / \mathrm{ml})$ & $<0,001$ & $<0,001$ & $<0,001$ & $<0,001$ & $<0,001$ & $<0,001$ & $<0,001$ & - & - \\
\hline 6 & $\mathrm{Cu}(\mathrm{ppm})$ & $<0,007$ & $<0,007$ & $<0,007$ & $<0,007$ & $<0,007$ & $<0,007$ & $<0,007$ & 30 ppm & - \\
\hline 7 & $\mathrm{Zn}(\mathrm{ppm})$ & $<0,001$ & $<0,001$ & $<0,001$ & $<0,001$ & $<0,001$ & $<0,001$ & $<0,001$ & $100 \mathrm{ppm}$ & $n$ \\
\hline
\end{tabular}




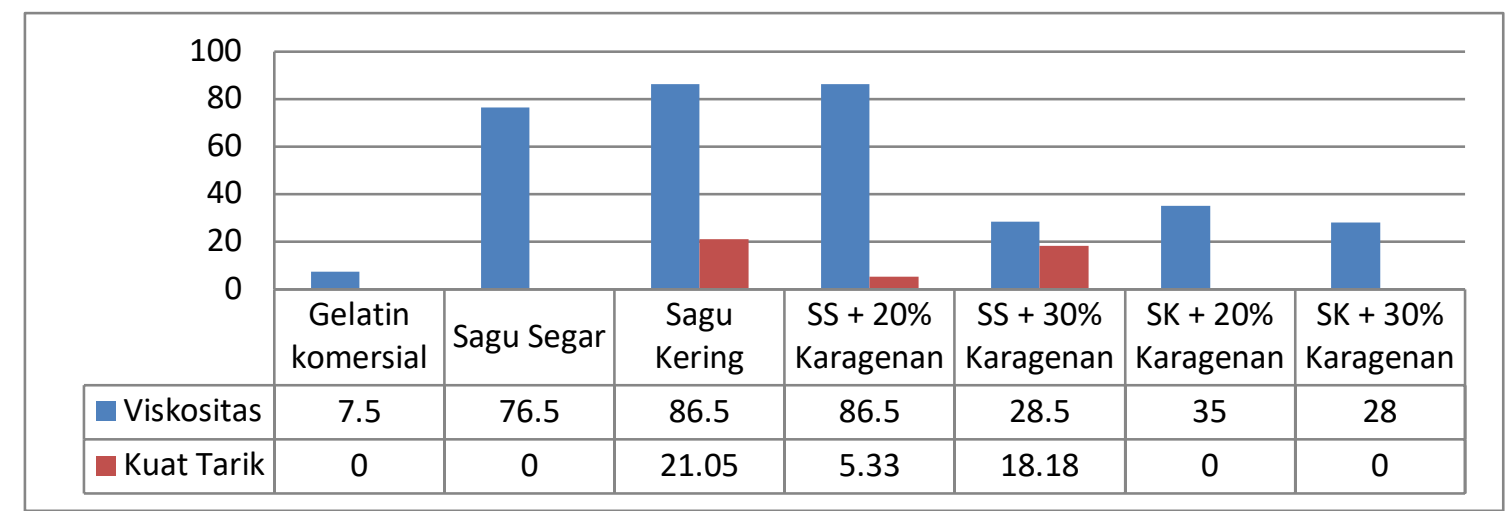

Gambar 2. Grafik Hubungan Viskositas (cp) dengan Kuat Tarik $\left(\mathrm{kg} / \mathrm{cm}^{2}\right)$ Edible Film (ss: sagu segar; sk: sagu kering)

Viskositas merupakan kemampuan menahan dari suatu cairan untuk mengalir. Berdasarkan Tabel 2 nilai viskositas yang didapat sangat tinggi, terutama pada variasi data tanpa agen modifikasi. Hal ini disebabkan sifat dari pati sagu yang mudah mengental akibat pengaruh turunnya suhu campuran. Salah satu faktor yang memiliki pengaruh besar terhadap tingginya nilai viskositas adalah suhu pada saat proses gelatinasi yang mengakibatkan ikatan yang terjadi semakin besar sehingga nilai viskositas naik, sedangkan pada campuran dengan karagenan konsentrasi $30 \% \mathrm{~b} / \mathrm{b}$ mampu menurunkan nilai viskositas ini sesuai dengan Dwi, Basmal, \& Nurochmawati (2005) yang menyatakan bahwa fragmentasi polimer karagenan dapat menurunkan berat molekul polimer karagenan sehingga nilai viskositas menurun. Gambar 2 menjelaskan mengenai hubungan antara viskositas dengan kuat tarik edible film.

Pada Gambar 2 tersaji hubungan antara viskositas dan kuat tarik. Supeni (2012) pada penelitiannya menyatakan bahwa viskositas berpengaruh terhadap ketebalan edible film sehingga akan mempengaruhi kuat tarik. Tensile strength merupakan daya renggang maksimum yang dapat diterima film sebelum putus. Hasil analisa (Gambar 2) kuat tarik edible film yang dihasilkan dari campuran pati sagu dan karagenan mempunyai kecenderungan untuk naik kemudian turun, berkisar dari yang paling rendah 5,33 $\mathrm{kg} / \mathrm{cm}^{2}$ hingga $21,05 \mathrm{~kg} / \mathrm{cm}^{2}$ dari grafik yang disajikan terlihat bahwa hubungan viskositas dengan kuat tarik tidak berpengaruh nyata $(p \geq 0,05)$. Bahan dasar pati sagu untuk pembuatan edible film bersifat kurang elastis serta memiliki nilai kekuatan tarik yang rendah. Menurut Ban (2005) faktor penting yang dapat mempengaruhi sifat fisik adalah affinitas antara komponen penyusunnya. Affinitas sendiri merupakan suatu fenomena dimana suatu atom atau molekul tertentu memiliki kecenderungan untuk bersatu dan berikatan. Oleh sebab itu, selain dimodifikasi dengan karagenan pati sagu ini juga harus dimodifikasi untuk dapat meningkatkan kuat tarik, salah satunya adalah dengan metode hidroksipropilasi menggunakan propilen oksida (Rahaju Maulani, Fardiaz, Kusnandar, \& Candra Sunarti, 2013), sehingga dalam tujuannya sebagai subtituen gelatin untuk pembuatan cangkang kapsul dapat memenuhi standar mutu industri.

\section{KESIMPULAN DAN SARAN}

Pati sagu kering adalah bahan baku paling baik yang memenuhi kriteria standar mutu SNI 06-3735-1995 dari segi organoleptik warna, bau, kadar air, kadar abu dan kandungan logam berat. Penambahan karagenan sebagai bahan modifikasi edible film sagu mampu menurunkan viskositas larutan pati. Semakin tinggi konsentrasi karagenan yang ditambahkan semakin rendah viskositas yang dihasilkan. Penggunaan 
pati sagu memiliki potensi untuk digunakan sebagai bahan baku cangkang kapsul, sehingga perlu dilakukan penelitian pati sagu termodifikasi agar memenuhi syarat mutu cangkang kapsul.

\section{UCAPAN TERIMAKASIH}

Terima kasih kami sampaikan kepada Balai Riset dan Standardisasi Industri Banjarbaru yang memberikan fasilitas dalam penelitian. Kami juga mengucapkan terimakasih atas dana penelitian yang telah diberikan untuk penelitian ini, sehingga penelitian ini dapat diselesaikan tepat waktu.

\section{DAFTAR PUSTAKA}

Ban, W. (2005). Improving the Physical and Chemical Functionally of StarchDerived Films with Biopolymers. Journal of Applied Polymer Science, 10, 118-129.

Basmal, J., Syarifudin, \& Ma'ruf, W. F. (2003). Pengaruh Konsentrasi dan Rasio Larutan Potasium Hidroksida dan Rumput Laut terhadap Mutu Karagenan Kertas. Jurnal Penelitian Perikanan Indonesia, 11(8), 95-103.

Bunga, S. M., Montolalu, R. I., Hari, J. W., Kedua, Montolalu, L. A., Watung, A. H., \& Taher, N. (2013). Karakteristik Sifat Fisika Kimia Karaginan Rumput Laut Kappaphycus alvarezii pada Berbagai Umur Panen yang Diambil dari Daerah Perairan Desa Arakan Kabupaten Minahasa Selatan. Jurnal Media Teknologi Hasil Perikanan, 1(2), 54-58.

Dwi, T. H. S., Basmal, J., \& Nurochmawati. (2005). Studi Pembuatan Edible Film dari Karagenan. Jurnal Penelitian Perikanan Indonesia, 11(4), 1-13.

Fatriani. (2010). Produktivitas Pembuatan Atap Rumbia (Metroxylon sagu Rottb) dan Kontribusinya terhadap Pendapatan Pengrajin di Desa Jambu Hulu Kecamatan Padang Batung Kabupaten Hulu Sungai Selatan Kalimantan Selatan. Banjarbaru:
Universitas Lambung Mangurat.

Hakim, A. R., Wibowo, S., Arfini, F., \& Peranginangin, R. (2011). Pengaruh Perbandingan Air Pengekstrak, Suhu Presipitasi, dan Konsentrasi Kalium Klorida (KCl) terhadap Mutu Karaginan. Jurnal Pascapanen dan Bioteknologi Kelautan dan Perikanan, 6(1), 1-12.

Heriyanto, N. M. (2011). Kandungan Logam Berat pada Tumbuhan, Tanah, Air, Ikan dan Udang Di Hutan Mangrove. Jurnal Penelitian Hutan Tanaman, 8(4), 197-205.

Herliany, N. E., Santoso, J., \& Salamah, E. (2013). Karakteristik Biofilm Berbahan Dasar Karaginan. Jurnal Akuatika, IV(1), 10-20.

Ozdemir, M., \& Floros, J. D. (2008). Optimization of Edible whey Protein Films Containing Preservatives for Mechanical and Optical Properties. Journal of Food Engineerering, (58), 475-481.

Paranginangin, R., Mulyasari, Sari, A., \& Tazwir. (2005). Karakterisasi Mutu Gelatin yang Diproduksi dari Tulang Patin (Pangasio hypothamos) secara Ekstraksi Asam. Jurnal Penelitian Perikanan Indonesia, 11(4).

Polyana, F. J., \& Puturuhu, B. R. I. (2016). Preparasi dan Karakterisasi Pati Sagu Asetil. Buletin Penelitian BIAM, VI(56), 10-13.

Purnama, R. C. (2003). Optimasi Proses Pembuatan Karaginan dari Rumput Laut Eucheuma cottonii. Bogor: Institut Pertanian Bogor.

Rahaju Maulani, R., Fardiaz, D., Kusnandar, F., \& Candra Sunarti, T. (2013). Sifat Fungsional Pati Garut Hasil Modifikasi Hidroksipropilasi dan Taut Silang. Jurnal Teknologi dan Industri Pangan, 24(3), 60-67. https://doi.org/10.6066/jtip.2013.24.1.6 0

Saputro, Dovan, T., Kurniawan, R., \& Nata, I. F. (2016). Konversi Pati Ubi Nagara (Ipomoea batatas L) Khas Kalimantan 
Selatan sebagai Sumber Bahan Baku Gelatin. In Pemanfaatan Sumber Daya Alam dengan Teknologi Terbarukan dan Ramah Lingkungan: Tantangan dan Peluang Di Masa Depan (pp. 134-138). Banjarbaru.

Sukri, \& Nanda. (2006). Karakteristik Alkali Treated Cottonii (ATC) dan Karaginan dari Rumput Laut Eucheuma cottonii pada Umur Panen yang Berbeda. Perikanan dan IImu Kelautan. Bogor: Institut Pertanian Bogor.

Supeni, G. (2012). Pengaruh Formulasi Edible Film dari Karagenan tehadap Sifat Mekanik dan Barrier. Jurnal Kimia Kemasan, 34(2), 281-285.

Suptijah, P., Suseno, S. H., \& Anwar, C. (2013). Gel Strength Analysis of Jelly Candy Produced from Shark Skin Gelatin with Addition of Carrageenan and Seaweed. Jurnal Pengolahan Hasil Perikanan Indonesia, 16(2), 183-191.

Suptijah, P., Suseno, S. H., \& Kurniawati. (2012). Aplikasi Karagenan sebagai Cangkang Kapsul Keras Alternatif Pengganti Kapsul Gelatin. Jurnal Pengolahan Hasil Perikanan Indonesia, 15(3), 223-231.

Wattimena, D., Ega, L., \& Polnaya, F. J. (2016). Karakteristik Edible Film Pati Sagu Alami dan Pati Sagu Fosfat dengan Penambahan Gliserol. Agritech, 36(3), 247-252. 